\title{
ARAH DAN MODEL PEMBINAAN MUALLAF DEWAN DAKWAH ACEH DAN FORUM DAKWAH PERBATASAN
}

\author{
Juhari Hasan \\ Universitas Islam Negeri Ar-Raniry Banda Aceh \\ jauhari.hasan@ar-raniry.ac.id
}

\begin{abstract}
Abstrak
Penelitian ini bertitik tolak dari minimnya perbatian terbadap pembinaan kaum muallaf yang diberikan oleh banyak pihak, baik bersifat individu maupun organisasi. Dalam kondisi ini dijumpai ada dua organisasi Islam, yaitu Dewan Dakwah Islam Aceh (DDA) dan Forum Dakwah Perbatasan (FDP) yang serius memberikan perhatian terhadap pembinaan Muallaf, terutama mereka yang menjadi muslim sebagai bagian dari keberhasilan dakwah FDP dan $D D A$. Karena itu penelitian dilakukan di kedua organisasi Islam ini dengan pendekatan kualitatif. Proses pengumpulan data dilakukan dengan teknik wawancara,observasi dan studi dokumen. Hasil penelitian menunjukkan bahwa terdapat 3 (tiga) arah pembinaan yang dilakukan, yaitu bina Agama, Bina Ekonomi dan Bina Pendidikan. Untuk melakukan pembinaan terhadap ketiga sisi tersebut, maka diperlukan model yang efektif. Berdasarkan data yang dikumpulkan menunjukkan ada 2 (dua) model pembinaan yang selama ini dilakukan banyak pibak, yaitu (1) Model Strukturalis, dan (2) model Kolaboratif. Dari kedua model ini, kolaboratif merupakan model yang dipraktikean oleh FDP dan DDA dalam membina kaum muallaf baik melalui pendekatan personal, silaturrahmi maupun halaqah. Bila dikaitkan dengan teori Constructuralis karya Von Glasersfield maka pembinaan agama dan ekonomi dilakukan melalui proses pendidikan. Glasersfield menyimpulkan bahwa pendidikan memegang peran strategis dalam melakukan pemberdayaan masyarakat, khususnya para muallaf.
\end{abstract}

Kata Kunci : Pembinaan Muallaf, Dewan Dakwah Aceh dan Forum Dakwah Perbatasan.

\begin{abstract}
Abstracs
This research based on the low of attention to coaching of muallaf by many parties, both individuals and organizations. In this case, found two Islamic organizations namely Dewan Dakwah Aceh and the Forum Dakwah Perbatasan which seriously paid attention to empowering of the Muallaf, especially those who became Muslims as part of the process of their dakwah activities. Therefore the research was carried out in these two Islamic organizations with a qualitative approach. The data collection process was carried out by interviewing, observing and studying documents. The results of the research showed 3 (three) directions of coaching,
\end{abstract}




\section{Jurnal Agama dan Sosial Humaniora}

namely Religious Development, Economic Development and Education Development. To do coaching on these three sides, an effective model is needed. Based on the data collected, it shows that there are 2 (two) coaching models that have been carried out by many parties, namely (1) the Structuralist Model, and (2) the Collaborative Model. Based on these models, collaborative is one of a model that is practiced by the FDP and DDA in fostering the muallaf through personal, friendship and halaqah approaches. In relation to the theory of Constructuralist by Von Glasersfield, religious and economic development is carried out through the educational process. Glasersfield concluded that education is a strategic role in empowering the community, especially the Muallaf.

Keywords : Muallaf empowering, Dewan Dakwah Aceh, and Forum Dakwah Perbatasan.

\section{A. Pendahuluan}

T slam adalah agama dakwah. Ia akan mengalami perkembangan bila didakwahkan. Sebaliknya, Islam akan mengalami kemunduran dalam suatu komunitas bila tidak didakwahkan. Selama ini, dakwah sering dipahami secara sempit dan terbatas pada aktivitas mimbar semata. Padahal dakwah memiliki cakupan yang sangat luas (komprehensif). Setiap unsur ajakan kepada kebaikan dan seruan meninggalkan kejahatan adalah dakwah. Di antara ajakan untuk berbuat baik adalah melakukan dakwah kepada orang-orang kafir yang belum mendapatkan informasi yang benar tentang Islam agar mereka menerima Islam sebagai agamanya.

Upaya dakwah untuk mengajak orang kafir untuk menerima Islam terasa sangat minim dilakukan oleh da'i sehingga orang-orang kafir yang memeluk Islam sebagiannya bukanlah hasil dari kerja dakwah para da'i, akan tetapi mereka sendiri yang terpanggil untuk menerima ajaran Islam menjadi bagian dari hidupnya. Mereka yang telah berupaya meninggalkan keyakinan lamanya dan memilih Islam sebagai jalan hidupnya sudah sepantasnya mendapatkan pembinaan dan perlakuan yang baik dari saudaranya. Umat Islam juga seharusnya mengajak semua pihak untuk menyantuni, membina dan membimbing saudara barunya untuk hidup layak sesuai dengan tuntunan ajaran Islam.

Dalam ajaran Islam, orang-orang yang baru meninggalkan agama lamanya untuk memeluk Islam disebut dengan "muallaf". Mereka merupakan anggota baru dari masyarakat Islam yang masih memerlukan pembinaan baik pembinaan keimanan, pembinaan peribadatan, pembinaan akhlak, pembinaan ekonomi dan lain-lain. Pembinaan tersebut seharusnya dilakukan oleh umat Islam secara suka rela (ikhlas) sehingga saudara barunya akan merasa menjadi bagian dari umat Islam secara utuh dan menyeluruh. Perhatian saudaranya yang sudah dari awal menjadi muslim akan menjadi 


\section{Jurnal Agama dan Sosial Humaniora}

Volume 9 Nomor 1 Juli 2021 13-26

E-ISSN 2597-9175

P- ISSN 2338-2341

tali pengikat ukhwah islamiyah antar sesama umat Islam. Ukhwah inilah yang menjadi salah satu kekuatan umat Islam dalam menghadapi berbagai persoalan sosial yang terjadi dari masa ke masa.

Muatan dan harapan dari ajaran Islam untuk peduli terhadap sesama, khususnya terhadap orang-orang yang baru menerima dan memilih Islam menjadi jalan hidupnya merupakan sebuah pilihan mulia yang seharusnya dilakukan oleh umat Islam secara baik. Namun tidak semua umat Islam saat ini, baik dalam bentuk individu maupun organisasi yang memberikan kepedulian serius terhadap kaum muallafin. Istilah "tidak semua" menunjukkan masih ada orang atau kelompok tertentu yang peduli terhadap pembinaan kaum muallaf. Di antaranya adalah Forum Dakwah Perbatasan (FDP) dan Dewan Dakwah Aceh (DDA).

Pengamatan awal terhadap kedua organisasi Islam ini mengindikasikan adanya perhatian serius dalam melakukan pembinaan terhadap kaum muallaf, terutama dikawasan perbatasan Aceh dengan Sumatera Utara, khususnya di Kabupaten Aceh Singkil, Kabupaten Aceh Tenggara dan Kota Subulussalam. Pada kajian ini penulis memfokuskan kajian pada arah dan pembinaan yang dilakukan oleh Dewan Dakwah Aceh dan Forum Dakwah Perbatasan terhadap para muallaf di daerah perbatasan

\section{B. Metode Penelitian}

Untuk menjawab kedua pertanyaan di atas, maka dilakukan proses pengumpulan data di kedua organisasi Islam ini. Penelitian ini menggunakan pendekatan kualitatif dengan menjadikan wawancara mendalam (in-depth interview), studi dokumentasi dan observasi partisipasi terbatas sebagai teknik pengumpulan data. Wawancara dilakukan dengan beberapa informan, baik dari pengurus Dewan Dakwah Aceh (DDA) maupun pengurus Forum Dakwah Perbatasan (FDP) dan beberapa orang Muallaf yang sedang dibina oleh kedua organisasi Islam ini. Data yang telah dikumpulkan selanjutnya dianalisis dengan menggunakan teknik analisis yang digunakan Miles dan Huberman melalui 3 (tiga) tahapan, yaitu melakukan reduksi, penyajian data dan penarikan kesimpulan.

\section{Interpretasi Muallaf}

1. Makna Muallaf.

Kata “ Muallaf” diambil dari bahasa Arab, yaitu اللف - يئا لف - مئلفة yang bermakna lembut atau lunak. Dalam Kamus al-Munawir disebutkan bahwa kata muallaf diambil dari kata "al-ulfah" yang bermakna jinak atau lunak. ${ }^{1}$ Secara terminologis dijumpai beberapa penjelasan para ilmuan terkait makna muallaf, antara lain :

${ }^{1}$ Ahmad Warson Munawir, 1997, Kamus Al-Munawir, Pustaka Prograsif, Surabaya, hlm. 34. 


\section{Jurnal Agama dan Sosial Humaniora}

a. Imam as-Syafe'I, sebagaimana dikutip oleh Ramlah Hakim, menjelaskan bahwa Muallaf adalah orang-orang yang baru menjadi muslim dengan kondisi keimanannya yang masih lemah. ${ }^{2}$

b. Al-Qurtubi menjelaskan bahwa Muallaf adalah orang-orang yang hidup di zaman Rasulullah dan telah menganut Islam pada masa awal perkembangan Islam dan masih memiliki keimanan yang belum kuat. ${ }^{3}$

c. Ali Azis mengkategorikan Muallad menjadi 2 (dua) kelompok, yaitu : (1) orangorang yang baru memeluk Islam dan masih memiliki tingkat keimanan yang belum kuat; (2) orang-orang kafir yang tertarik hatinya terhadap Islam. ${ }^{4}$

Dari beberapa penjelasan di atas dapat dikemukakan bahwa Muallaf adalah orang kafir, baik perorangan maupun kelompok yang telah menyatakan diri memeluk Islam. Setiap orang yang menyatakan dirinya memeluk Islam telah disebut sebagai orang Islam meskipun memiliki motif yang berbeda-beda. Meskipun berbeda motif dalam memilih Islam, namun wajib bagi umat Islam lainnya untuk menjaga, melindungi, membina dan memeliharanya dari berbagai ancaman, baik ancaman kemiskinan, kebodohan maupun ancaman kehidupan lainnya.

\section{Pendekatan dalam pembinaan Muallaf.}

Pembinaan kaum muallaf bukanlah hal yang mudah dilakukan, karena secara psikologis mereka masih memiliki tingkat kegoncangan psikologis yang tinggi dan sangat rentan terhadap situasi baru yang sedang dijalaninya. Karena itu diperlukan pendekatan tertentu yang bersifat persuasif sehingga mereka lebih mudah menerima pembinaan dari saudara barunya dalam agama Islam. Tulisan ini mencoba mengangkat beberapa pendekatan yang dipandang cukup efektif dalam rangka membina kaum muallafin di Aceh, antara lain :

a. Pendekatan Personal dan silaturrahmi

Kedua pendekatan ini dijelaskan oleh Dirjen bimbingan masyarakat Islam Kementerian Agama Jakarta. Kedua pendekatan tersebut dapat dijabrkan sebagai berikut :

1) Pendekatan Personal (personal approach): Personal approach digunakan dengan cara membina kedekatan emosional/ psikologis antara para pembina dengan para muallaf. Pendekatan ini dipandang cukup efektif dalam rangka memberikan bantuan berupa pembinaan dan pencerahan pemahaman keislaman bagi orang-orang yang baru saja memeluk Islam. ${ }^{5}$ Melalui pendekatan ini, akan terbangun hubungan emosional yang

2 Ramlah Hakim, 2012, Pola Pembinaan Muallaf di kabupaten Sidrang Sulawesi Selatan, dalam Jurnal AlQalam, vol.9 nomor 1 Januari 2013, hlm. 3. hlm.434.

${ }^{3}$ Al-Qurtubi, 2008, Tafsir al-Qurtubi, Terj. Al-Jami' lil abkamil Qur'an, Pustaka Azam, Jakarta,

${ }^{4}$ Ali Azis, 2009, Ilmu Dakwah, cet.II, Kencana, Jakarta, hlm.256.

${ }^{5}$ Kementerian Agama Republik Indonesia, 2012, Materi Bimbingan Agama Pada masyarakat Muslim Pemula (Muallaf), Dirjen Bimbingan Masyarakat Islam, Jakarta, hlm.26. 
sangat dekat di antara kedua entitas ini. Umat yang baru saja bergabung menjadi muslim akan merasakan adanya perhatian dan kebersamaan di tengah-tengah saudara barunya, sehingga ia tidak merasa terasing apalagi tersisih ketika berada di tengah umat Islam lainnya.

2) Pendekatan Silaturrahmi: Selain pendekatan Personal, ada juga pendekatan lain yang tidak kurang pentingnya dilakukan terhadap saudara baru umat Islam, yaitu pendekatan silaturrahmi. Silaturrahmi merupakan tindakan saling bertemu dan mengunjungi satu sama lain sehingga akan terbangun sekaligus memperkuat rasa solidaritas dan kasih sayang antar sesama, khususnya antara umat Islam dengan kaum muallf. ${ }^{6}$ Dalam Islam, ajaran tentang silaturrahim ini dibahas secara bersahaja oleh Rasulullah, para sahabat dan para ulama setelahnya.

Bila dilihat pada peristiwa sejarah hijrahnya Rasulullah dari Mekkah ke Medinah akan dijumpai sebuah peristiwa besar yang membuat dakwah Rasulullah menjadi besar dan kuat, yaitu mempersaudarakan (silaturrahmi) antara muhajirin dari Mekkah dengan kaum Anshar yang berada di Medinah. Pertemuan dan silaturrahmi/ ukhwah Islamiyah yang dibangun oleh Rasulullah telah menjadi model tersendiri bagi pembinaan umat Islam yang paripurna. Secara teori simbolik, peristiwa hijrah yang melambangkan adanya persaudaraan antara pendatang yang membaur dengan penduduk asli Medinah itu menggambarkan bahwa ketika kaum muallf yang baru bergabung ke dalam ajaran Islam harus dipersaudarakan dengan umat Islam yang telah terlebih dahulu berada dalam Islam. Perpaduan antara kaum muslimin (sebagai kaum anshar) dengan para muallafin (kaum muhajirin) merupakan sebuah keniscayaan yang mesti dibangun dalam rangka memperkokoh Ukhwah Islamiyah.

\section{b. Pendekatan Halaqah}

Halaqah pada dasarnya diartikan dengan lingkaran. Istilah ini dipahami dari bentuk pangajian yang dilakukan oleh Rasulullah terhadap para sahabatnya dalam mengajarkan Islam. Para sahabat duduk melingkar mendengarkan penjelasan Nabi tentang ajaran Islam. Pendidikan dan dakwah dengan pendekatan ini terus berkangsung dari masa ke masa hatta saat ini. Hanum Asrohah menjelaskan halaqah ini sebagai salah satu pendekatan pembinaan kaum muallaf dan umat Islam secara menyeluruh. Pendekatan ini mengedepankan bentuk dialogis dalam menjelaskan Islam kepada muallaf. Karena itu mereka dapat mencari dan menemukan solusi atas segala permasalah yang dihadapinya pasca masuk Islam. ${ }^{7}$

Halaqah memiliki efektifitas tinggi dalam proses dakwah dan pendidikan umat. Dipandang efektif karena bisa berkomunikasi dan berkonsultasi secara langsung

${ }^{6}$ Kementerian Agama, .......hlm.34.

${ }^{7}$ Hanum Asrohah, 1999, Sejarah Pendidikan Islam, Logosm Jakarta, hlm.49-50. 


\section{Jurnal Agama dan Sosial Humaniora}

dengan nara sumber atau da'i sehingga hal-hal yang masih bersifat dhanni dapat diperjelas dengan baik. Dalam proses pembinaan muallaf, halaqah dipandang sebagai suatu pendekatan yang efektif dilakukan, tidak saja untuk penguatan keimanan atau pembinaan kerohanian, akan tetapi juga dalam melakukan pembinaan ekonomi dan kreatifitas sosial lainnya.

\section{Teori Pemberdayaan.}

Muallaf merupakan orang-orang yang lemah, baik keimanan maupun lemah ekonominya, sehingga merke perlu diberdayakan sehingga tumbuh dan berkembang menjadi orang-orang yang kuat dan menjadi muslim yang paripurna. Salah satu teori pemberdayaan masyarakat diungkapkan oleh Kieffer bahwa ketidakberdayaan seseorang atau kelompok didominasi oleh proses interaksi seseorang dengan lingkungan sekitarnya sehingga menimbulkan ketidakpercayaan diri, merasa terasing di lingkungan sekitarnya. ${ }^{8}$ Sikap ini telah membunuh kreatifitas seseorang sehingga telah berdampak pada ketidakmampunnya menghadapi lingkungan yang mengintarinya.

Selain Kieffer, Learner, sebagaimana dikutip oleh Suharto, juga mengatakan bahwa ketidakberdayaan yang dialami seseorang atau sekelompok orang diakibatkan oleh proses internalisasi dari proses interaksi yang terjadi dalam masyarakat. ${ }^{9}$ Kedua teori pemberdayaan ini menekankan pengaruh lingkungan sebagai unsur penentu ketidakberdayaan seseorang atau kelompok tertentu dalam masyarakat. Karena itu, untuk memberdayakan masyarakat - khususnya kaum muallaf - maka logikanya adalah memperkuat setiap muallaf untuk mampu beradaptasi dengan lingkungan sosialnya. Untuk maksud ini maka proses empowering bagi para muallaf merupakan sesuatu yang tidak bisa dihindari.

Dalam rangka membentuk pemberdayaan kaum muallaf, ditemukan sebuah teori menarik yang dikemukakan oleh Von Glasersfeld yang dikenal dengan teori Constructivist. Glasersfeld mengatakan bahwa akar dari teori ini adalah pembentukan pengetahuan. Teori Konstruktivitas lebih mengedepankan proses sesuatu - terutama proses belajar - dari pada hasil yang dicapai. ${ }^{10}$ Dalam membangun pemberdayaan masyarakat, teori pembelajaran ini perlu kedepankan agar masyarakat mampu mengkonstruksikan pemahamannya untuk perubahan dengan tetap memelihara tata nilai yang yang telah diterima sebelumnya.

Bila teori di atas dikaitkan dengan pemberdayaan kaum muallaf, maka pengenalan terhadap lingkungan sosial yang mengelilinginya dipandang sebagai sesuatu yang penting dilakukan sehingga para muallaf dapat berinteraksi dan beradaptasi dengan

${ }^{8}$ Kieffer, C.H, 1984, Citizen Empowerment : A Developmental Perspective, Prevention in Human Service, USA. Vol. 3, hlm.9.

${ }^{9}$ Edi Suharto, 2006, Membangun Masyarakat Memberdayakan Rakyat, Refika Aditama, Bandung, hlm.61.

${ }^{10}$ Abbeduto. Leonard, 2004, Taking Sides : Clashing Views on Controversial Issues in Educational Psycology, Mc.Graw - Hill, third edition, Dushkin, hlm. 73 


\section{Jurnal Agama dan Sosial Humaniora}

Volume 9 Nomor 1 Juli 2021 13-26

E-ISSN 2597-9175

P- ISSN 2338-2341

lingkungan yang ada. Tidak hanya memperkenalkan lingkungan sosial, para muallaf juga perlu dididik dengan bergagai ketrampilan sehingga mampu mengenali lingkungan yanga ada sehingga mampu membangun kekuatan ekonominya agar bisa berkembang menjadi muallaf yang berdedikasi, berdikari dan dan berwawasan keislaman yang komprehensif.

\section{Motif Menjadi Muallaf}

Setiap orang yang menjatuhkan pilihannya pada sesuatu, termasuk memilih Islam sebagai agama yang dianutnya tentu memiliki motif yang berbeda-beda. Thomas F.O'Dea melalui teori Konversi Agama menjelaskan bahwa seseorang pindah agama (menjadi muallaf) dikerenakan adanya adanya kecendeungan utk mencari nilai-nilai baru yang ada dalam hidupnya. ${ }^{11}$ Hendropuspito menjelaskan bahwa seseorang bisa saja pindah agama ke agama baru yang disebabkan antara lain oleh adanya suasana batin seseorang yang tidak menentu. Krisis kejiwaan atau kegoncangan jiwa atas realitas kehidupan social mampu menjadi pemiu seseorang beralih agama. ${ }^{12}$

Dua penjelasan di atas memberikan gambaran bahwa seseorang pindah agama, dalam hal ini adalah menjadi Muslim, ikut dipengaruhi oleh suasai batin seseorang. Siasana batin ini memperlihatkan adanya naluri dari setiap orang untuk mencari dan menemukan kebenaran yang hakiki. Mungkin saja kebenaran yang selama ini diyakini tidak bersifat korespondensi dengan kenyataan-kenyataan yang dialami oleh seseorang. Di saat seseorang menemukan adanya ketenangan jiwa setelah melakukan sesuatu atau mengikuti suara hatinya, maka ia akan memutuskan akan mengikuti ajakan rohaniyahnya menuju Tuhan. Karena itulah ia menjadi muslim.

Dalam penelitian yang dilakukan di Forum Dakwah Perbatasan (FDP) dan Dewan Dakwah Aceh (DDA), ditemukan beberapa alasan/ motif seseorang menganut Islam sebagai agamanya. Bila diklasifikasi secara rinci, maka ada didapati ada 2 (dua) dorongan seseorang menjadi Muslim (muallaf), yaitu :

\section{Motif Internal.}

Berpijak dari penjelasan Hendropuspito di atas bahwa suasana batin seseorang memiliki pengaruh cukup kuat bagi terjadinya pindah agama. Secara Psikologis, setiap orang sulit untuk membantah suara hatinya, karena pada dasarnya manusia itu memiliki sifat Fitrah yaitu menyukai kebenaran. Hanya saja lingkungan social yang dialaminya telah membuat ia tidak berani mengikuti bisikannya sendiri. Terkait dengan penjelasan tersebut, dijumpai beberapa motif menjadi muallaf selama dilakukan proses pengumpulan data di FDP dan DDA, antara lain :

11 Thomas F. O’Dea, 1990, The Sociology of Religion, terj. Tim Penerjemah Yasogama, Rajawali press, Jakarta, hlm. 116.

${ }^{12}$ D. Hendropuspito, 1983, Sosiologi Agama, Kanisius, Yogyakarta, hlm 85. 


\section{Jurnal Agama dan Sosial Humaniora}

\section{Volume 9 Nomor 1 Juli 2021 13-26 \\ E-ISSN 2597-9175 \\ P- ISSN 2338-2341}

a. Faktor Hidayah.

Faktor hidayah ini agak sulit bisa dijelaskan karena ia bersifat abstrak. Akan tetapi seseorang bisa menjadi muslim dikarenakan factor hidayah. Hal ini disebutkan oleh Abdullah Jasanta Ginting - salah seorang Muallaf binaan FDP dan DDA yang menyebutkan secara terbuka motif ia menjadi muslim. Abdullah mengatakan bahwa ia menjadi Muslim disebabkan oleh adanyanya dorongan hati yang secara terus menerus mengajaknya menjadi muslim. Awalnya ia menolak perasaannya, namun semakin lama dorongan itu semakin kuat dan klimaksnya adalah menemui salah seorang da’i FDP di Kota Subulussalam minta untuk disyahadatkan. ${ }^{13}$

\section{b. Faktor Ingin mencari kebenaran.}

Kebenaran adalah fitrah. Setiap orang cenderung untuk mencari dan menemukan kebenaran hakiki dalam rangka mendapatkan ketenangan batiniyahnya.Ferdinan juga menyebutkan adanya rasa tidak nyaman ketika selama ini ia membaca dan mempelajari kitab ajaran agama yang selama ini diyakininya. Ia merasakan adanya kondisi yang kurang dapat diterima akal sehatnya atas beberapa penjelasan dari kitab suci yang pegangnya. Akhirnya ia memilih Islam untuk menemukan ketenangan hati dan pikirannya. Ia mengakui bahwa sejak menjadi bagian dari umat Islam ia mulai menemukan kesejukan hatinya yang sulit bias dilukiskan dalam bentuk kata atau kalimat. Namun intinya adalah sejak menjadi muslim ia merasakan ketengan jiwa yang cukup luar biasa. ${ }^{14}$

Ust.Zaini, salah seorang Pembina Muallaf menyebutkan bahwa mereka yang telah bersyahadat memeluk Islam - di samping adanya usaha-usaha dakwah yang terus menerus kita lakukan, faktor takdir Allah juga merupakan faktor penentu seseorang itu menjadi muallaf. Sebab dalam agama kita, Allah hanya memerintahkan kita untuk berdakwah saja, sedangkan pintu hidayah tetap ada dalam kekuasaan Allah Swt. Dia mencontohkan sdr Ferdinan yang saat ini sedang dalam pembinaan, ia menjadi muslim karena ingin mencari kebenaran yang sesungguhnya, maka ia sendiri yang meminta untuk disyahadatkan secara sadar dan bersahaja. ${ }^{15}$

\section{Motif Eksternal.}

a. Faktor Perkawinan.

Di samping faktor internal terdapat juga motifasi eksternal, yaitu adanya keinginan untuk menikah dengan laki-laki/ perempuan muslim. Terjadi faktor

\footnotetext{
${ }^{13}$ Hasil Wawancara dengan Abdullah Jasanta Ginting, salah seorang muallaf asal Sumatera utara yang menjadi Muallaf di Kota Subulussalam, 21 Maret 2021.

${ }^{14}$ Hasil wawancara dengan sdr Ferdinan, warga Kecamatan Danau paris, Singkil yang saat ini sedang belajar tentang Islam di Akademi Dakwah Aceh.

${ }^{15}$ Wawancara dengan Ust. Zaini, Pembina Muallaf di Akademi Dakwah Indonesia, Aceh, 20 Maret 2021.
} 
perkawinan juga menjadi alasan seseorang untuk pindah agama. Ustaz Zaini menguraikan bahwa tidak sedikit orang pindah agama atau menjadi muslim dengan alasan ingin menikah dengan perempuan muslimah atau dengan laki-laki muslim. Ia menembahkan adanya 2 fenomena menarik yang terjadi pada keluarga yang pindah agama dengan alasan perkawinan; (1) terus bertahan sebagai seorang muslim dengan berbagai situasi yang dihadapinya; (2) ada juga yang kembali ke agama sebelumnya setelah merasa tidak lagi cocok dengan pasangan yang dinikahinya. ${ }^{16}$

\section{b. Faktor Lingkungan sosial.}

Setip lingkungan social selalu memberikan warna dan pengaruh terhadap pola pikir masyarakatnya. Karena itu lingkungan social dimana seseorang itu hidup selalu ikut memupuk jiwa dan pola pikir dirinya terutama dalam bersikap dan bertindak. Ustaz Zaini menyebutkan, lingkungan memilik pengaruh cukup besar terhadap pola piker dan perilaku seseorang. Bila seseorang berteman dengan lingkungan orang-orang baik maka ia juga cenderung menjadi orang baik. Bagitu juga sebaliknya seseorang akan jahat manakala ia bergaul dengan lingkungan yang tidak kondisif.

\section{c. Faktor Keuntungan ekonomi.}

Motif lain menjadi muallaf adalah karena ingin mencari keuntungan ekonomi. Beberapa orang non-muslim mengetahu persis bahwa Islam memiliki system ekonomi tersendiri, seperti pengeluaran zakat, infaq dan sadakah di kalangan umat Islam. Bagi sebagain masyarakat non muslim, mereka memeluk Islam karena ingin memiliki pendapatan lebih dari apa yang mereka peroleh saat menjadi non muslim.

Salah seorang pengurus FDP menjelaskan, orang memeluk Islam itu tidak selalu ingin cari kebenaran, akan tetapi juga mencari keuntungan, terutama keuntungan ekonomi. Mereka tahu kalau dalam Islam itu ada zakat yang diperuntukkan bagi mereka yang kurang mampu (miskin). Karena itu kemiskinan yang selama ini melanda mereka dan belum ditemukan solusinya, maka ia akan menjadi muslim sehingga mendapatkan keuntungan ekonomi tersebut. ${ }^{17}$

\section{Hasil Penelitian Dan Pembahasan}

1. Arah pembinaan

Organisasi FDP dan Dewan Dakwah telah merancang arah pembinaan muallaf yang efektif sehingga proses pembinaan kemandirian muallaf dapat dicapai dengan baik. Hasil wawancara dengan informan dijelakan bahwa ada 3 arah pembinaan yang sedang dilakukan FDP dan DDA saat ini, antara lain:

a. Bina Agama

${ }^{16}$ Wawancara dengan ust. Zaini, Pembina Muallaf pada Dewan Dakwah Aceh, 20 maret 2021.

${ }^{17}$ Hasil wawancara dengan Dr Abizal Muhd. Yati, pengurus FDP, 18 Maret 2021. 


\section{Jurnal Agama dan Sosial Humaniora}

Untuk bina Agama, FDP dan DDA sudah menyiapkan para ustaz untuk menjadi Pembina dan penanggung jawab aktivitas pembinaan kaun muallafin ini. Untuk bidang keagamaan, mereka dididik ilmu pengetahuan dalam bidang Tauhid atau penguatan akidah. Di samping itu juga diberikan materi tentang ibadah, baik dalam bentuk teori maupun praktik, seperti praktik berwudhu', shalat, dan lain-lain. Pembinaan lain adalah membentuk akhlakul karimah agar para muallafin ini bisa berperilaku baik dan islami. Penguatan bidang agama ini menjadi salah satu binaan penting karena memperkokoh keyakinan mereka terhadap Allah seraya menyerehkan diri secara total kepada Allah Swt.

Berdasarkan diskusi-diskusi yang dilakukan bersama ketua FDP terungkap bahwa agama - menurutnya - merupakan fondasi utama yang mesti diperkuat terlebih dahulu sebelum memperkuat sisi-sisi lainnya. Bila agama' khusunya keimanan kepada Allah telah mapan maka pembinaan yang lain seperti pembinaan ekonomi, budaya dan lain-lain akan berjalan di atas roda keimanan itu. ${ }^{18}$ Dialog ini memperlihatkan penting penguatan keislaman khususnya ketauhidan bagi para muslim pemula (muallaf) sehingga keyakinannya terhadap Allah akan dapat dijiwai dengan baik dan sempurna.

\section{b. Bina Ekonomi}

Dalam bidang ekonomi, FDP dan DDA telah merancang lahirnya koperasi syariah yang dijadikan sebagai pusat bina ekonomi muallaf. Melalui koperasi ini mereka diberikan modal usaha untuk mengembangkan ekonomi dan kemandirian mereka. Beberapa upaya penguatan ekonomi yang dilakukan seperti Training pada Balai Latihan Kerja (BLK), praktik menjahit, bisnis susu kedelai dan Perahu dakwah, yaitu sebuah boat berkapitas 50 orang yang bisa dipergunakan untuk berbagai kepentingan dakwah dan pembinaan masyarakat. Meskipun usaha ini tampak belum berjalan maksimal, tapi paling tidak sudah ada gagasan-gagasan dan niat baik untuk melakukan penguatan ekonomi para muallafin ini.

Zaini mengungkapkan, para muallaf ini juga manusia biasa yang secara naluriah memiliki kebutuhan-kebutuhan tertentu dalam hidupnya. Karena itu para pembina dan umat Islam semuanya harus memikirkan pengembangan ekonomi bagi mereka. Ia menambahkan, keimanan mereka sangat boleh jadi akan menurun manakala pemenuhan terhadap kebutuhan dasarnya belum terpenuhi dengan baik. Karena itu pengembangan ekonomi merupakan salah satu unsur yang cukup urgen untuk diperhatikan bagi perkembangan dan kemandrian muallaf. ${ }^{19}$

${ }^{18}$ Hasil Wawancara dengan ketua FDP, 15 maret 2021.

${ }^{19}$ Hasil wawancara dengan ust. Zaini, pembina muallaf di Dewan Dakwah Aceh, 20 maret 2021. 
c. Bina Pendidikan

Bina pendidikan merupakan salah satu upaya yang sedang dilakukan Dewan Dakwah dan Forum Dakwah Perbatasan (FDP) dalam rangka mewujudkan kemandirian muallaf. Dr Abizal menjelaskan, salah satu bentuk kepeduliah FDP dan DDA terhadap dunia pendidikan, diberikan beasiswa bagi anak/ remaja untuk melanjutkan pendidikan. Salah satu lokasi pembinaan pendidikan terhadap anak para muallaf adalah di Pondok Pesantren Ar-Rabwah Indrapuri Aceh Besar. Di samping di Ar-Rabwah juga dilakukan pendidikan di Akademik Dakwah Indonesia (ADI) Aceh. ${ }^{20}$ Pernyataan ini juga dapat disaksikan keberadaan mereka di kedua lembaga pendidikan yang disebutkan di atas. ${ }^{21}$

Ketiga arah pembinaan ini memiliki nilai yang cukup strategis bagi pembinaan kaum muallafin. Manakala pembinaan keagamaan, ekonomi dan pendidikan telah berjalan dengan baik, maka secara otomatis roda pembinaan sudah mulai berjalan dan dalam waktu tertentu diharapkan akan melahirkan muallaf yang kuat, mandiri dan bermartabat.

\section{Model Pembinaan}

Tidaklah mudah untuk melakukan pembinaan terhadap orang-orang yang baru memeluk Islam ini. Diperlukan kesabaran, kesungguhan dan juga memerlukan model pembinaan yang baik dan strategis. Dalam menelusuri aktivitas binaan yang dilakukan FDP dan DDA di Aceh dijumpai paling tidak ada 2 (dua) model Pembinaan kaum Muallaf, yaitu sebagai berikut :

\section{a. Model Strukturalis}

Strukturalis merupakan sebuah model yang selama ini berjalan. Pembinaan model ini cenderung dilakukan secara struktural oleh pemerintah melalui lembaga terkait, seumpama kerjasama dengan Kementerian Agama dan Baitul Mal. Kedua lembaga ini telah memberikan perhatian kepada kaum muallafin ini sesuai dengan mekanisme yang ada. Namun ketika dianalisis lebih dalam, model strukturalis ini memiliki kelemahan sehingga berjalan kurang maksimal. Di antara penyebab kekurangmaksimalan model ini disebabkan oleh para pembina yang terdiri dari Pegawai Negeri Sipil (PNS) yang harus bekerja sesuai mekanisme jam kantor. Di samping itu mereka juga memiliki beban kerja lain yang tidak kalah pentingnya untuk diselesaikan setiap hari, sehingga perhatian untuk pembinaan para muallafin otomatis tidak terfokus. Di tambah lagi dengan pergerakan pembinaan yang dilakukan secara mandiri oleh masing-masing lembaga. Sementara para da'i yang berada dibawah kendali FDP dan DDApun kurang maksimal dalam menjalankan tugasnya sebagai pembina kaum muallafin.

${ }^{20}$ Wawancara dengan Dr Abizal Muhd.Yati, Pengurus FDP, 19 maret 2021.

${ }^{21}$ Hasil observasi tanggal 18 Maret 2021. 


\section{Jurnal Agama dan Sosial Humaniora}

\section{b. Model Kolaboratif}

Model Kolaboratif merupakan sebuah model pembinaan dengan melibatkan para pihak sesuai dengan kemampuan dan profesionalisme masing-masing. Model ini bergerak secara serentak sesuai bidang masing-masing. Model ini ditemukan praktiknya di dalam organisasi FDP dan DDA yang secara bersahaja telah menyusun rencana pembinaan dengan pola pembagian kerja (Job discreption) yang teratur. ${ }^{22}$ Kedua organisi Islam juga berupaya merekrut lembaga dan organisai lain untuk ikut ambil bagian dalam proses pembinaan kaum Muallafin. Menurut Ust. Zaini selama ini sudah ada beberapa lembaga dan organisasi Islam yang bergabung untuk mensukseskan program pembinaan muallaf, antara lain Dinas Syariat Islam Provinsi Aceh, Rumah Zakat, Da'i Perkotaan Kota Banda Aceh, Pesantren Ar-Rabwah. Semua lembaga dan organisasi ini bergerak sesuai bidang masing-masing. FDP misalnya bergerak sebagai motivator yang selalu membangkitkan semangat untuk peduli terhadap Muallafin. DDA menyiapkan tenaga dan fasilitas binaan yang difokuskan di sekretariat Dewan Dakwah Aceh dan Akademik Dakwah Indonesia Aceh yang bermarkas di Gampong Rumpet Kecamatan Krueng Barona Jaya. Rumah Zakat menyiapkan dana zakat yang secara khusus dialokasikan untuk pembinaan masyarakat, khususnya para Muallafin ini. Demikian pula dengan organisasi lain seumpana Da’i Kota Banda Aceh yang secara aktif membangkitkan motivasi beragama dan beribadah bagi para muallaf ini. ${ }^{23}$

Bila dibanding kedua model ini, maka model kedua, yaitu kolaboratif memiliki banyak keunggulan dalam mempraktikkan upaya pembinaan kaum Muallaf di Aceh. Kelebihan model ini adalah mempu menggerakkan semua potensi dan sumberdaya yang ada untuk berdakwah dan pembinaan masyarakat, sehingga melahir pergerakan yang serentak sesuai bidang dan profesi masing-masing. Inilah yang dimaksudkan dalam ungkapan Saidina Ali bin Abi Thalib dengan :

\section{الحق بلا نظام يغلبه الباطل بالنظام}

Dalam perspektif manajemen dakwah, inilah yang maksud dengan kerja terorganisir, dan terencana dengan baik. Kerja yang terencana, teratur dan terukur biasanya akan berujung pada kesuksesan dan sebaliknya, pekerjaan yang dilakukan tanpa perencaan yang matang sering membuahkan kegagalan dan kekecewaan.

\section{E. Kesimpulan}

Berdasarkan uraian pada hasil penelitian, penulis dapat memberikan beberapa kesimpulan sebagai berikut; pertama, ada 2 (dua) model pembinaan muallaf yang

22 Wawancara dengan Dr H Abizal Muhammad Yati, Pengurus DDA dan juga FDP, 18 pebruari

${ }^{23}$ Wawancara dengan ust. Zaini, Pembina Muallaf di DDA Aceh, Pebruarin 2021. 


\section{Jurnal Agama dan Sosial Humaniora}

Volume 9 Nomor 1 Juli 2021 13-26

E-ISSN 2597-9175

P- ISSN 2338-2341

dilakukan, yaitu Model Strukturalis dan Model Kolaboratif. Kedua, proses pembinaan muallaf lebih efektif bila dilakukan dengan model Kolaboratif yaitu sebuah model yang melibatkan para pihak yang bekerja sesuai bidang dan profesiolisme masing-masing dengan tetap mengikuti garis komando. Ketiga, secara manajemen dakwah, pergerakan pembinaan yang dilakukan oleh masing-masing lembaga dan organisasi yang terkoordinasikan dalam barisan kerja sesuai job masing-masing (Manajemen strategis). Keempat, model kolaboratif dapat dijadikan role model bagi pengembangan dan kemandirian para muallaf. Kelima, proses pembinaan kaum muallaf, muaranya adalah tetap mengedepankan proses dakwah dan pendidikan kepada mereka untuk memahami agama barunya dan juga belajar memahami keadaan sekitarnya sehingga melahirkan para muallaf yang mapan dan mandiri. Keenam, umat Islam, baik yang memiliki kekuasaan (struktural) maupun yang memiliki pengaruh sosial dalam masyarakat (kultural) termasuk di dalamnya berbagai organisasi Islam harus bergerak bersama untuk memperkuat kaum muallafin ini untuk menjadi bagian dari umat Islam yang kuat dan utuh.

\section{DAFTAR BACAAN}

Abbeduto. Leonard, 2004, Taking Sides : Clashing Views on Controversial Issues in Educational Psycology, Mc.Graw - Hill, third edition, Dushkin.

Ahmad Warson Munawir, 1997, Kamus Al-Munawir, Pustaka Prograsif, Surabaya.

Ali Azis, 2009, Ilmu Dakwah, cet.II, Kencana, Jakarta.

Al-Qurtubi, 2008, Tafsir al-Qurtubi, Terj. Al-Jami' lil abkamil Qur'an, Pustaka Azam, Jakarta.

D. Hendropuspito, 1983, Sosiologi Agama, Kanisius, Yogyakarta.

Edi Suharto, 2006, Membangun Masyarakat Memberdayakan Rakyat, Refika Aditama, Bandung.

Hanum Asrohah, 1999, Sejarah Pendidikan Islam, Logosm Jakarta.

Kementerian Agama Republik Indonesia, 2012, Materi Bimbingan Agama Pada masyarakat Muslim Pemula (Muallaf), Dirjen Bimbingan Masyarakat Islam, Jakarta.

Kieffer, C.H, 1984, Citizen Empowerment : A Developmental Perspective, Prevention in Human Service, USA.

\begin{tabular}{l|l|l}
\hline Diterbitkan Oleh: & Juhari Hasan \\
Lembaga Studi Agama dan Masyarakat Aceh (LSAMA) & Arah dan Model Pembinaan Muallaf Dewan Dakwah Aceh dan Forum Dakwah Perbatasan \\
Banda Aceh. Azman 085261631481 & \\
http://journal.Isamaaceh.com/ & & \\
Isamaaceh@gmail.com & &
\end{tabular}


Jurnal Agama dan Sosial Humaniora

\begin{tabular}{|l|l|l}
\hline Volume 9 Nomor 1 Juli 2021 13-26 & E-ISSN 2597-9175 & P- ISSN 2338-2341
\end{tabular}

Ramlah Hakim, 2012, Pola Pembinaan Muallaf di kabupaten Sidrang Sulawesi Selatan, dalam Jurnal Al-Qalam, vol.9 nomor 1 Januari 2013.

Thomas F. O'Dea, 1990, The Sociology of Religion, terj. Tim Penerjemah Yasogama, Rajawali press, Jakarta, hlm. 116.

A. 